Education 3-13: International Journal of Primary, Elementary and Early Years Education https://www.tandfonline.com/doi/abs/10.1080/03004279.2019.1572769

\title{
Primary school children's beliefs associating extra-curricular provision with non-cognitive skills and academic achievement
}

\author{
Jane Murray ${ }^{1}$ and David Cousens ${ }^{2}$ \\ ${ }^{1}$ Centre for Education and Research, University of Northampton, UK \\ ${ }^{2}$ Faculty of Education and Humanities, University of Northampton, UK
}

\begin{abstract}
This article focuses on the beliefs of primary school children aged 7-11 years in England concerning the impact of adult-led after-school extended provision (EP) on their development of non-cognitive skills (NCS). In responses to a questionnaire survey and focus group interviews, children were more positive than parents, teachers and school governors, believing EP enabled them to acquire numerous NCS, including most emotional intelligence competences, but excluding social skills related to locus of control. Findings support the argument that EP affording NCS development may enhance academic achievement, indicating that NCS development embedded in primary curricula may also benefit academic achievement.
\end{abstract}

\section{Introduction}

In a global context of increased focus on schools' performativity (Ball, 2003; Lingard, Nixon and Ranson, 2008), extending the school day for children has become more common in some countries. The extended school day has been viewed as a valuable tool for tackling socioeconomic disadvantage and securing global competitiveness, yet conversely as an unwelcome incursion into children's home lives (Gromada and Shewbridge, 2016). Attempts to establish a causal link between an extended day and academic performance have elicited mixed results, and such studies have tended to focus narrowly on academic achievement (Patall, Cooper and Allen, 2010). This article presents and discusses insights from children's data that were collected as part of a small-scale participant-oriented evaluation study commissioned by Baginton Primary School (BPS), for which the school's parents, governors, staff and children aged 7-11 years shared their beliefs concerning the impact of extended provision on children's motivation for learning and aspirations for their future during one academic year. Motivation and aspiration are non-cognitive skills (NCS) that have been associated with learning and development (Gutman and Schoon, 2013; Khattab, 2015). Aspiration inspires motivation by offering hope and optimism, which, with other attitudinal characteristics, may enhance human capital (Kasim and Dzakiria, 2001; Sellar, Gale and Parker, 2011). Motivation may be intrinsic or extrinsic (Ryan and Deci, 2000) and motivation, aspiration, hope and optimism are characteristics of emotional intelligence (EI) theory (Goleman, 1995). 
BPS is a small rural primary school in an English county where school students' attainment has consistently scored below average in national tests in recent years (Ofsted, 2014). The school received additional funding from its local authority for one year to set up 'Baginton University' (BU): an optional extended school day for pupils aged 7-11 years, providing practical activities focused on NCS development. Since learners' beliefs are powerful forces in motivation to learn and academic achievement (Lin-Siegler, Dweck and Cohen, 2016) and children may be considered 'experts in their own lives' (Langsted, 1994:42), this article focuses on children's views concerning their NCS acquisition through extended provision. In respect of the study's primary focus on motivation and aspiration, findings indicate participating children's beliefs that wide-ranging extra-curricular activities they experienced in extended school provision gave them motivation to learn and enhanced their aspirations for the future. Because of established associations between motivation, aspiration, hope, optimism and EI theory (Goleman, 1995), EI theory was applied to children's data, revealing that the children believed their experiences of extended provision enabled them to acquire a wide range of NCS, including EI skills. Taking into account these points, alongside extant research associating NCS with academic achievement (Agasisti and Longobardi, 2016; Durlak, Weissberg, Dymnicki, Taylor and Schellinger, 2011; Perez-Gonzalez, Cejudo-Prado and Duran-Arias, 2014), we argue that extended provision focused on NCS development that was experienced by the children in this study has potential to enhance their academic achievement. That argument has implications for techno-rational educational practices.

\section{Background to the Study}

This section locates the present study in literature concerning motivation for learning, aspiration and emotional intelligence, as well as children's participation rights and performativity in education.

\section{Motivation for learning}

Ryan and Deci (2000) define intrinsic motivation as '... activity for its inherent satisfactions' (p.56) and extrinsic motivation as activity '...to attain some separable outcome' (p.60). They regard intrinsic motivation as optimal for learning and achievement but observe that many school experiences children have 'are not designed to be intrinsically interesting' (p.60). Lingard et al. (2008) suggest that learners are motivated by tasks they regard as meaningful, 
while Pintrich (1999) prioritises three models of motivation for learning: (i) self-efficacy beliefs, (ii) task value beliefs and (iii) goal orientations.

\section{Motivation in School}

Pintrich's view (1999) is shared by others in respect of motivation in schools. Hu, Jia, Plucker and Shan (2016) posit that motivation to learn influences academic achievement. External factors - for example cultural context - nurture students' motivation in school (Guay, 2016; Havu-Nuutinen and Niikko, 2014), whereas internal factors - for example selfbeliefs - motivate students to learn in school, so can affect academic achievement (LinSiegler et al. 2016). Acquisition of critical thinking skills also impacts positively on children's motivation to learn (Hu et al., 2016), as do self-efficacy and self-regulation (Bedford, 2017; Voronova, Korneev and Akhutina, 2015). Moreover, Cleary and Kitsantas (2017) suggest that school students' 'motivational beliefs' that they can complete a task successfully, find the task interesting and feel supported enable them to self-regulate, with positive impact on academic learning.

\section{Motivation out of School}

Several studies associate extra-curricular engagement, motivation to learn and academic achievement. Wünschmann, Wüst-Ackerman, Randler, Vollmer and Itzek-Greulich (2017) found that out-of-school provision enhanced primary children's motivation and selfdetermination, leading to higher academic achievement, and Kasim and Dzakiria (2001) propose that recreation can impact positively on academic achievement. Equally, young people with motivational goals oriented to mastery and performance are more likely to engage in extra-curricular activity $(\mathrm{Ng}, 2015)$, and Fischer and Theis (2014) identify that experiencing challenge and support in extra-curricular activity enhances children's motivation to learn and achieve in school.

\section{Aspiration and Extra-curricular Activities}

School can be an important locus for (re)producing aspiration (Holloway and Pimlott-Wilson, 2011): aspiration in education includes 'attitudes, motivation and expectation' (Kasim and Dzakiria, 2001: 53). Aspiration is 'what an individual hopes will happen in the future' (Gorard, See and Davies, 2012:6), so is associated with goal setting and hope (Grant, 2017). Hope is 'a condition for the possibility of leading a human life' McGreer (2004: 102) which inspires motivation and optimism (Goleman, 1995). Individuals' aspirations often relate to 
social and economic progress (Sellar, Gale and Parker, 2011; Gustafsson, 2016) and neoliberal policymakers have identified that extra-curricular activities provide lifelong advantages, with potential to promote aspiration and social mobility (Her Majesty's Government (HMG), 2009; Holloway and Pimlott-Wilson, 2011). Seldon (2015) argues that it is how extra-curricular activities enable students to learn NCS including teamwork, empathy, resilience, creativity, honesty and grit that create this advantage. These NCS, among others, are features of social and emotional learning (SEL), life skills and EI that are also linked to academic achievement (Agasisti and Longobardi, 2016; Durlak et al. 2011; Murray and Garner, 2015; Perez-Gonzalez et al. 2014).

\section{Emotional Intelligence}

Both motivation and aspiration align with EI theory, a cognitive ability linked to general intelligence, but distinguishable from it (Gardner, 1983; Goleman, 1995; Mayer and Salovey, 1997). EI is defined as the ability to perceive, use, understand and manage emotions in oneself and others (Mayer and Salovey, 1997), although it has attracted controversy (Wilhelm, 2008). Whilst EI is considered fundamental to success in contemporary life (Marin, 2013) and EI theory is regarded as 'a useful framework' for predicting success in different domains and understanding how emotional information is processed (Salovey and Grewal, 2005), conversely, it has been identified as a 'myth' lacking the rigour necessary for 'good scientific theory' (Matthews, Zydner and Roberts, 2002:15; Brody, 2004). Yet Goleman (1995; 2009) advocates that schools should support children to develop SEL, listing five EI competences: motivation, self-awareness, self-regulation (resilience), empathy and social skills (Table 1) and his work has influenced practice in many schools: numerous programmes have emerged to support NCS development (Murray and Garner, 2015).

Table 1: EI competences and sub-sets (Goleman, 2009)

\begin{tabular}{|l|l|}
\hline \multicolumn{1}{|c|}{ EI Competences for managing self } & EI Competences for managing others \\
\hline $\begin{array}{l}\text { Motivation } \\
\text { - Initiative }\end{array}$ & Social Skills \\
- Achievement drive & - Building bonds \\
- Optimism & - Collaboration and cooperation \\
- Commitment & - Influence \\
& $\begin{array}{l}\text { - Communication } \\
\end{array}$ \\
& - Conflict management \\
Self-awareness & Empathy \\
- Emotional awareness & - Understanding others \\
\hline
\end{tabular}




\begin{tabular}{|c|c|}
\hline $\begin{array}{ll}\text { - Accurate self-assessment } \\
\text { - Self-confidence }\end{array}$ & $\begin{array}{ll}\text { - } & \text { Service orientation } \\
\text { - } & \text { Political awareness } \\
\text { - } & \text { Developing others }\end{array}$ \\
\hline $\begin{array}{ll}\text { Self-regulation } \\
\text { - } & \text { Self-control } \\
\text { - } & \text { Trustworthiness } \\
\text { - } & \text { Conscientiousness } \\
\text { - } & \text { Adaptability } \\
\text { - } & \text { Innovation } \\
\end{array}$ & - Leveraging diversity \\
\hline
\end{tabular}

Nevertheless, schools in western cultures have attended increasingly to a performativity agenda focused on narrow, economically driven academic learning (Ball, 2013; Jeffrey and Troman, 2012). This has led to imperatives to justify SEL only in terms of its potential benefits for academic achievement and attainment (Durlak et al. 2011; Gutman and Schoon, 2013), or eliminate it to focus exclusively on academic attainment (Pratt, 2016: 891).

\section{Children's Voices}

Children's voices are 'views of children that are actively heard and valued as substantive contributions to decisions affecting the children's lives' (Brooks and Murray, 2018:145). Ignoring children's views may be detrimental to their academic attainment and achievement, since autonomy, self-regulation and critical thinking are factors in motivation to learn that are associated with academic achievement (Lin-Siegler et al., 2016; Hu et al., 2016; Cleary and Kitsantas, 2017; Van Ryzin, Gravely and Roseth, 2009). Research evidence suggests that children's voices are important for their learning, agency and participation rights (Lin-Siegler et al. 2016; Maybin, 2013; Office of the High Commissioner for Human Rights (OHCHR), 1989; Taylor and Robinson, 2009; Whitty and Wisby, 2007). However, 'often children's voices are not heard or not heeded' in educational contexts (Singer, 2014: 381).

\section{Learning as Performance?}

Despite powerful arguments that person-centred education and NCS are beneficial for lifetime outcomes, increasingly centralised approaches to children's academic achievement and attainment have emerged in recent years (Fielding and Moss, 2011; Seldon, 2015; Agasisti and Longobardi, 2016; Durlak et al. 2011). Contemporaneously, a plethora of influential international tools for monitoring and measuring children's learning performance have focused on investment return (Breakspear, 2012; UNESCO, 2016; IEA, 2017a, 2017b; Organisation for Economic Cooperation and Development (OECD), 2017a, 2017b; World 
Bank, 2017a, 2017b). However, the global industry that monitors and measures children's learning performance is fiercely contested (Auld and Morris, 2016; Ball, 2012; Fielding, 2004; Lingard et al. 2008; Moss, 2016b).

\section{Learning as Performance in England}

Successive governments in England have subscribed to the international 'testology' zeitgeist (Malaguzzi, in Cagliari, Castegnetti, Giudici, Rinaldi, Vecchi and Moss, 2016: 331; Winter, 2017) so that its education system is currently dominated by narrow academic standards and teaching to tests that measure the number of children who make required 'good progress', with schools' test results published in competitive league tables (Baker, Sammons, SirajBlatchford, Sylva, Melhuish and Taggart, 2014; Bates, 2016; Moss, 2016b; Ofsted, 2018:48; Wyse, Hayward and Pandya, 2016). Nevertheless, England's international PISA performance has remained mediocre (Adams, Weale, Bengtsson and Carrell, 2016).

The region of England where the present study was conducted had been characterised by poor test results for some years (Ofsted, 2014). In an attempt to address this situation, the region funded extra-curricular activities and BPS secured funding to set up BU, an optional offer of extended provision for BPS children aged 7-11 led by local professionals and volunteers, including opportunities for developing NCS that were not part of the BPS curriculum. Each after-school BU session comprised sports activities and a healthy snack, followed by projects with a life skills focus, for example, cooking, money management and first aid.

\section{Methodological Considerations}

\section{Aim, Objectives and Research questions}

BPS's head teacher commissioned this research 'to capture stakeholders' perspectives concerning the impact of BU's extended provision on children's motivation for learning and aspirations', so that was the study aim. Although this article focuses on the children's data, the full research design is outlined here to contextualise those data.

\section{The Selected Methodology, Participants and Researchers}

A participant-oriented evaluation model was adopted; including stakeholders' authentic attitudes and views concerning their own experiences assured trustworthy data (Lincoln and Guba, 1985; Fitzpatrick, Sanders and Worthen, 2010). The sample was purposive, with participants comprising BPS and BU staff, governors, children aged 7-11 years and their 
parents. Towards the end of one year of BU provision, all BPS and BU staff, governors, children aged 7-11 years and their parents $(n=250)$ were invited to complete a questionnaire survey, differentiated in presentation and language for children. Stratified samples of parents, staff, governors and child participants also attended three focus groups. The two researchers were experienced primary teachers and teacher educators, so were 'relative insiders' in the study (Griffiths, 1998: 137).

\section{The Selected Research Instruments}

Development of the research instruments was informed by Ryan and Deci's work on motivation (2000), a review of social and emotional learning (SEL) literature (Murray and Garner (2015) and the Motivated Strategies for Learning Questionnaire (MSLQ) (Pintrich, Smith, Garcia and McKeachie, 1999). The research design included a questionnaire survey (QS) and focus groups (FGs). The QS captured data from parents, staff and governors ( $\mathrm{n}=150)($ Research Instrument (RI) 1) and children aged 7-11 years who had attended BU (n=100) (RI 2) about children's experiences of the BU extended provision, including its impact on children's motivation for learning and aspirations. Themes that emerged from the questionnaire data informed the focus group interview schedule questions. Two FGs were conducted with adults $(\mathrm{n}=5)$ : one with $\mathrm{BU}$ and school staff and governors and one with parents. Another FG was conducted with children who had attended BU $(n=3)$. The number of focus group participants was small to elicit in-depth responses. The project was guided and regulated by the research team's institutional ethics code and procedures and the 2011 BERA Ethical Guidelines for Educational Research. Not only because of ethical requirements, but also because a major focus of the study was on children's agency and participation rights, the recruitment process was designed to enable potential child participants to feel free to decide for themselves whether they wished to participate: there was no coercion or requirement for them to do so. This approach resulted in low participation by children but afforded greater opportunity for in-depth responses from the three participating children than would have been possible with a larger group.

\section{Analysis}

Descriptive statistical analysis was applied to the structured elements of the QS and inductive thematic analysis was adopted for open responses in the QS and the FG data. Data were then subjected to secondary deductive analysis using the five EI domains (Goleman, 1995). 


\section{The Findings}

Because this article is concerned with children's self-beliefs as learners, the data that are presented and discussed are almost exclusively the children's.

\section{Questionnaire Findings}

All 100 children aged 7-11 years took the adults' and children's QS home and 15\% of children responded to the children's QS. The children's return was lower than the adults' (31\%), suggesting that adults may not have encouraged children to express their views, a finding that resonates with other research (Thornberg and Elvstrand, 2012). In their QS, children were invited to respond 'Yes' or 'No' to a range of statements concerning 'At BU' and 'BU has helped me to...' A final open question invited children to identify 'What is worst and best about BU?'.

\section{Children's Questionnaire Findings concerning Extended Provision}

Overall, children thought their experiences 'At BU' (Figure 1) motivated them to learn $(89 \%)$, although $73 \%$ of children disagreed with the statement 'BU is easy'.

Figure 1: Children's Questionnaire Survey 'At BU'

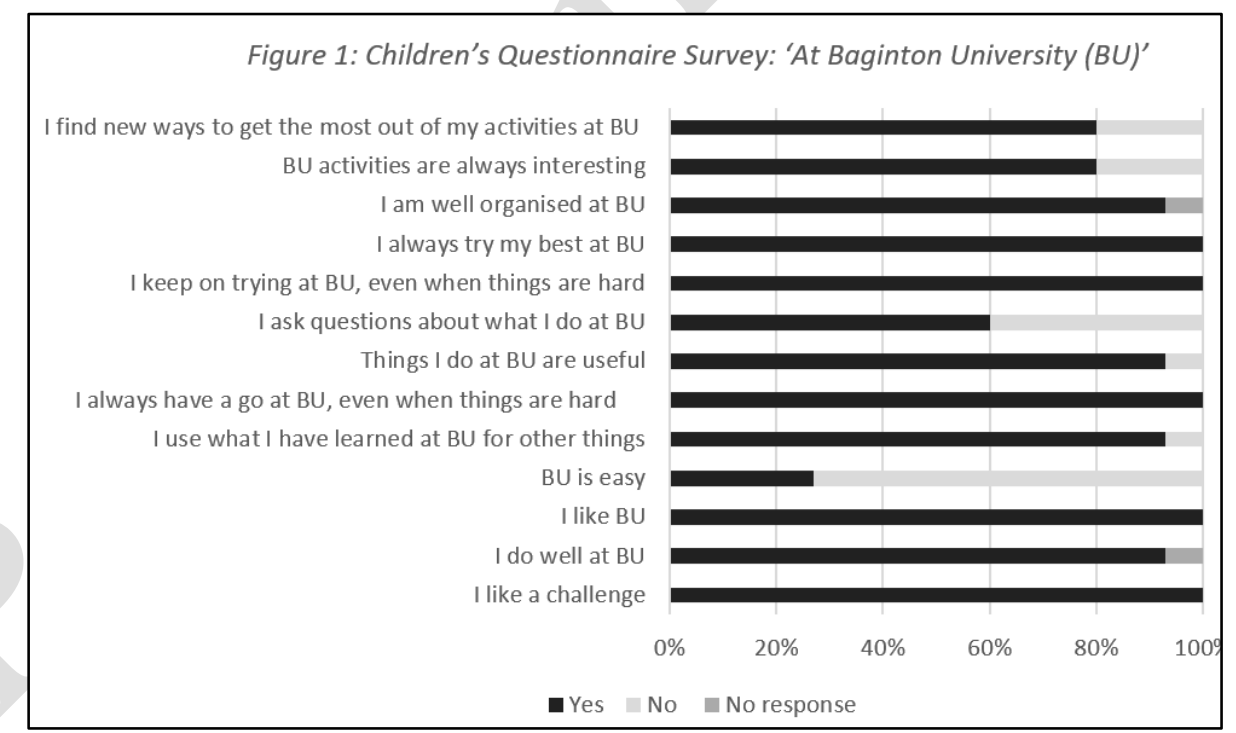

Results from the children's QS section 'BU has helped me to...' (Figure 2) indicate that 87\% of responding children thought BU had enhanced their motivation to learn in different ways. However, only $60 \%$ of children thought 'BU has helped me to tell people how I feel about things'.

Figure 2: Children's Questionnaire Survey 'BU has helped me to...' 


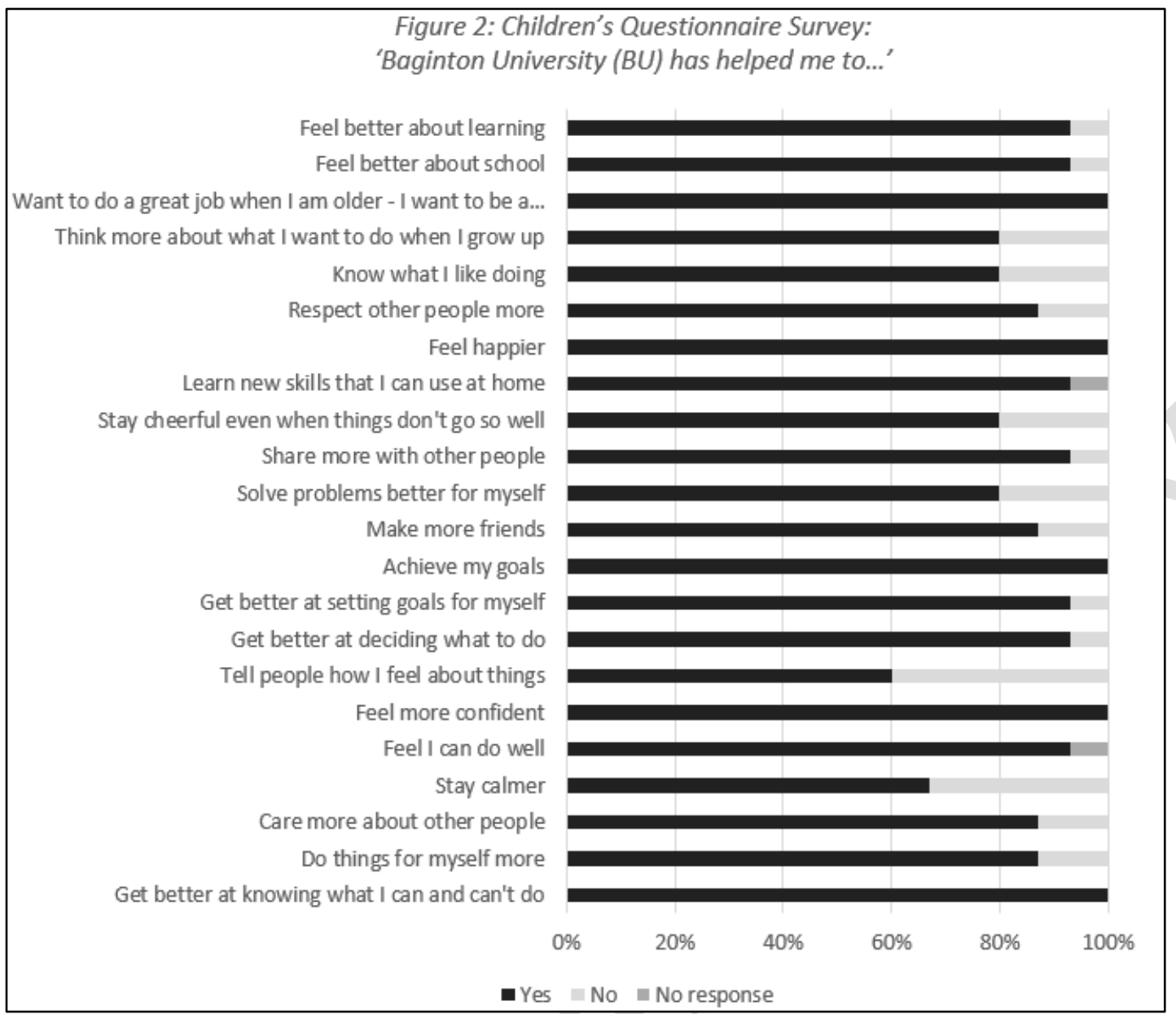

Two questions focused on aspiration: $80 \%$ of children thought 'BU has helped me to think more about what I want to do when I grow up', while 100\% revealed varied career aspirations (Table 2): 'BU has helped me to want to do a great job when I am older - I want to be a...'

Table 2: Children's career aspirations

\begin{tabular}{|l|}
\hline Teacher $(\mathrm{n}=2)$ \\
\hline Vet \\
\hline Zoo keeper \\
\hline Astronaut \\
\hline $\begin{array}{l}\text { Netballer, chef, DJ and } \\
\text { trampolining }\end{array}$ \\
\hline Dancer / performer \\
\hline Police Officer $(\mathrm{n}=2)$ \\
\hline Professional rugby player \\
\hline Dentist \\
\hline RAF pilot or architect \\
\hline Writer \\
\hline Gymnast \\
\hline Footballer or PE Teacher \\
\hline
\end{tabular}


In the final section of their QS, children indicated the BU features they liked worst and best (Table 3):

Table 3: Features of BU children liked least and best

\begin{tabular}{|l|l|}
\hline Features of BU children liked least & Features of BU children liked best \\
\hline $\begin{array}{l}\text { People are too noisy and we don't get much } \\
\text { done }\end{array}$ & It is fun (2) \\
\hline $\begin{array}{l}\text { Some of the activities I don't like: } \\
\text { photography, cooking, history }\end{array}$ & $\begin{array}{l}\text { I really like how all the adults care about the } \\
\text { children }\end{array}$ \\
\hline It's really long & You get to try new things \\
\hline $\begin{array}{l}\text { Cooking - didn't actually get to do the } \\
\text { cooking - just arrange it on a plate }\end{array}$ & $\begin{array}{l}\text { Dodge ball, science at JSA but not literacy. Things } \\
\text { on computers and doing things, hands on }\end{array}$ \\
\hline Choir Club & Netball (x3) \\
\hline Tikondo (sic: Taekwondo) & $\begin{array}{l}\text { Everyone there is really lovely and they make us } \\
\text { feel welcome. The activities are great! }\end{array}$ \\
\hline Nothing (2) & $\begin{array}{l}\text { Meeting new friends and getting to do the sports I } \\
\text { love }\end{array}$ \\
\hline Sometimes it makes me tired & I like acieving (sic: achieving) my goals \\
\hline $\begin{array}{l}\text { Sometimes people choose people that have } \\
\text { had the certificate and trophy }\end{array}$ & $\begin{array}{l}\text { I've been given a charns (sic: chance) to learn new } \\
\text { things }\end{array}$ \\
\hline People messing around & Learning and making friends \\
\hline When they don't do sports & Getting a snack in the middle \\
\hline
\end{tabular}

The children's positive QS responses concerning their experiences at BU also revealed awareness of their EI skills (Goleman, 1995), including self-awareness, e.g. 'I always try my best at BU (93\%), self-regulation, e.g. 'I am well organised at BU' (100\%), and social skills, e.g. 'BU has helped me to make more friends' $(87 \%)$.

Children's QS responses were more positive than parents', teachers' and school governors' QS responses concerning any beneficial associations between the extended provision and the children's motivation to learn and aspirations for the future (Figure 3).

Figure 3: Children's and Adults' views of Children's Motivation for Learning at School 


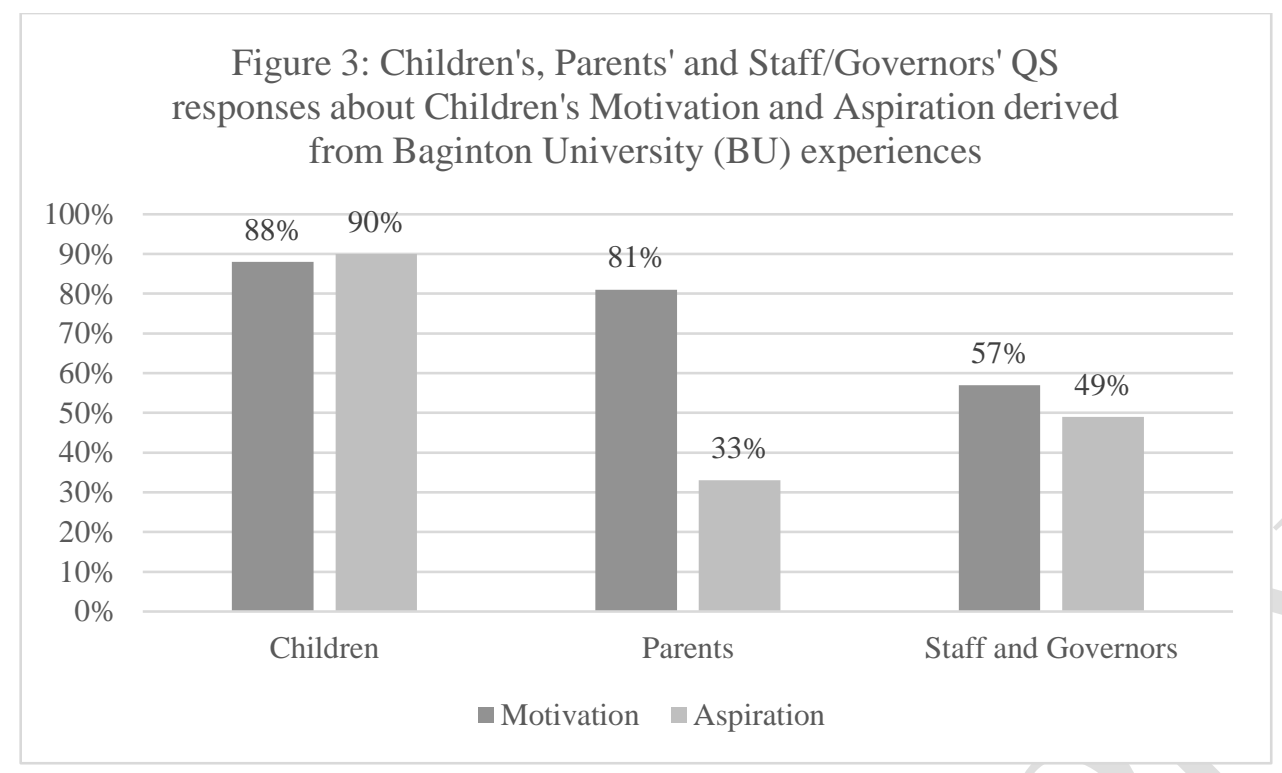

Equally, the children's QS responses not only indicated their motivation to learn and aspirations for the future but also revealed additional themes concerning their experiences of BU (Table 4).

Table 4: Additional Themes from the Children's Survey-Children's Experiences of BU

\begin{tabular}{|l|l|}
\hline $\begin{array}{l}\text { Themes from the } \\
\text { children's survey }\end{array}$ & Examples of data \\
\hline Children's Behaviour & $\begin{array}{l}\text { 'People are too noisy and we don't get much done' } \\
\text { 'Sometimes people choose people that have had the certificate } \\
\text { and trophy' }\end{array}$ \\
\hline Inequality & 'Everyone there is really lovely and they make us feel welcome' \\
\hline Relationships & 'It is fun' \\
\hline Enjoyment & $\begin{array}{l}100 \% \text { of children agreed 'BU has helped me to want to do a } \\
\text { great job when I am older' and they all identified career } \\
\text { aspirations }\end{array}$ \\
\hline Expectations & \begin{tabular}{l} 
'Getting to do the sports I love!' \\
\hline Activities
\end{tabular} \\
\hline Duration & \multicolumn{1}{|l}{ 's really long'. } \\
\hline
\end{tabular}

Interwoven with most of the themes that emerged from the children's QS, were their beliefs that the extended provision had supported them to develop EI skills, including selfawareness, self-regulation, empathy and social skills (Goleman, 1995; 2009). This aspect is discussed later (Table 4).

Key themes that emerged from the QS data informed the focus group interview schedules, including the children's interview schedule (Figure 4). The children's QS data were triangulated by FG data.

Figure 4: Focus Group (FG) Schedule for Children 


\section{Children's Views about Baginton University: Focus Group Schedule}

1. Most grown-ups who responded to the questionnaire said they thought children found learning easy at school but children said the opposite. Why do you think this is?

2. Most grown-ups who responded to the questionnaire said they thought children found learning easy at BU but children said the opposite. Why do you think this is?

3. What is the aim of BU?

4. Does BU achieve its aim?

5. a) Does BU help children to learn special skills that will help them later on? b) Do you know about children applying any skills they have learned at BU to other things they do?

6. Do you think BU makes a difference to the ways children think about school?

7. Do you have anything you would like to add about BU?

\section{Children's Focus Group Interview Findings}

Jack (age 8), John (aged 10) and Julian (age 8) (pseudonyms) chose to take part in the children's FG interview which lasted for 39.39 minutes and was conducted by the two researchers in BPS staff room following a school day. Themes that emerged from the FG data aligned with the two key aspects guiding the study; (i) children's motivation for learning and (ii) aspirations for their future. Within these themes, subordinate themes emerged in the children's FG narratives (Table 5).

Table 5: Focus Group Themes

\begin{tabular}{|l|l|}
\hline Motivation for Learning & Aspiration for the future \\
\hline Expectations & For now and in the future \\
Pedagogy & Opening doors \\
Impact & \\
Impediments to learning & \\
\hline
\end{tabular}

FG data were also subjected to analysis using Goleman's five EI domains (1995). Selected children's FG narratives are presented below, exemplifying subordinate themes in the data and how they link to Goleman's five EI domains (1995).

\section{Motivation for Learning: Expectations}

The children saw BU primarily as a place to do sport and homework, and a place that helped them to prepare for later life:

'(BU) helps you with your homework so you don't actually have to do it at home...giving me 
more knowledge...helps you with life beyond.' (Julian, 8).

Here, Julian's self-awareness and motivation emerge (Goleman, 1995).

\section{Motivation for Learning: Pedagogy}

Children suggested that 'fun', 'games', 'good lessons' and 'good learning' at BU motivated them to learn:

'It's easier to learn with BU because... they turn it into some sort of games' (John, $10)$.

'They have good lessons' (Julian, 8).

These responses indicate the children's self-awareness, motivation and empathy, showing their understanding about the work of the BU staff (Goleman, 1995).

\section{Motivation for Learning: Impact}

The subordinate theme 'Impact' subdivided into 'impact', 'end product' and 'transforming behaviours'. The FG children thought BU activities offered benefits:

'I think the aim (of BU) is to... to get us...to get our brains working and to help' (John, $10)$.

They also thought BU could have a transformative impact, for example, by providing opportunities to complete homework:

'One person like, was quite bad at maths, in our class and now he's quite good. I think

it's because they went to Homework Club' (Julian, 8),

or by helping children to change their behaviour:

'...in the beginning...if a ball touched (my friend), he would fall over crying, ...in a few

weeks...he would be able to say, "So, its hit me so what? We're playing dodgeball, I'll

just go and sit on the bench"' (John, 10).

'...because he's got anger problems. He's one of my best friends. Yeah he's changed after

$B U$, completely changed' (Jack, 8).

'Not changed in a bad way, changed in a good way' (John, 10).

Children also valued opportunities BU offered to help them to develop skills: 
'I've used (first aid) for Julian, erm, because he's got a massive gash in his knee... and

then he started crying, so knowing that the first rule in it was to keep calm I started telling Julian jokes' (John, 10).

These children's FG narratives concerning 'Motivation for Learning: Impact' also evidence their EI, including self-awareness, self-regulation, empathy and social skills (Goleman, 1995).

Motivation for Learning: Impediments to learning

FG children identified some impediments to their learning at BU. They suggested the acoustics in the hall prevented them from hearing others clearly and they also thought:

'Sometimes (adults leading sessions) don't explain it that well.' (Julian, 8) Children's critique of 'Impediments to learning' at BU indicates their ability to use their initiative to think critically, an aspect of motivation (Goleman, 1995).

Aspiration for the future: For now and in the future

The children identified BU activities they considered beneficial to children now and also for the future.

‘(BU)...helps you to design stuff, it helps you have sport, just because you might want to be a

famous something or other' (Julian, 8).

'Virgin Money Fiver Challenge, erm, it just helps me to like spend money wisely' (Jack, 8).

They discussed the value of the homework for now and the future:

'It gives you more knowledge and it helps you... it helps you with life beyond and if you're

like an inventor it might give you good ideas for inventions.' (Julian, 8)

FG children linked their ambitions for the future to a BU drawing activity:

'Yeah, I drew a scary monster because I want to be a Sci-fi story writer when I am older'

(Julian, 8)

'I want to be a zoo keeper and so I drew a zoo.' (Jack, 8) 
'I put the ISS in orbit around the earth and then put the sun in the top corner and then

Mercury and Venus and then put on one arm, a...the ESA badge.' (John, 10)

The children's self-awareness, self-regulation, motivation and empathy emerge in these narratives (Goleman, 1995).

\section{Aspiration for the future: Opening doors}

The children thought some BU experiences might lead to opportunities later in life:

'You could be like, the street dance of Diversity... one of the most famous street dances of

the world. It does, some of the stuff might... really inspire you and maybe you could

become famous... when you're older' (Jack, 8).

Here, Jack's self-awareness and motivation are revealed (Goleman, 1995).

\section{EI skills the children associated with $\mathrm{BU}$}

Themes in the children's data indicated that they associated their experiences at BU with skills across all five EI domains (Goleman, 1995). Those themes included aspiration, motivation, children's behaviour, inequality, relationships, enjoyment and expectations (Table 6).

Table 6: EI competences children associated with BU extended provision

\begin{tabular}{|l|l|l|l|}
\hline \multirow{2}{*}{$\begin{array}{l}\text { Themes in } \\
\text { children's data }\end{array}$} & $\begin{array}{l}\text { Goleman's 5 EI competences associated } \\
\text { with themes in children's data }\end{array}$ & $\begin{array}{l}\text { Sub-sections of Goleman's 5 } \\
\text { EI competences associated } \\
\text { with themes in children's data }\end{array}$ \\
\cline { 2 - 4 } & Managing self & Managing others & Self-Confidence \\
\hline $\begin{array}{l}\text { Aspiration } \begin{array}{c}\text { For now and in } \\
\text { the future }\end{array} \\
\text { - Opening doors }\end{array}$ & Self-awareness & & Achievement Drive \\
\cline { 2 - 4 } $\begin{array}{l}\text { Motivation } \\
\text { - Expectations } \\
\text { - Pedagogy } \\
\text { - Impact } \\
\text { - Impediments to } \\
\text { learning }\end{array}$ & Motivation & & $\begin{array}{l}\text { Achievement drive } \\
\text { Commitment } \\
\text { Initiative } \\
\text { Optimism }\end{array}$ \\
\hline $\begin{array}{l}\text { Children's } \\
\text { Behaviour }\end{array}$ & & & $\begin{array}{l}\text { Self-control } \\
\text { Conscientiousness } \\
\text { Adaptability } \\
\text { Innovation }\end{array}$ \\
\hline Inequality & Self-regulation & & Understanding others \\
\hline
\end{tabular}




\begin{tabular}{|l|l|l|l|}
\hline \multirow{2}{*}{ Relationships } & & & Leveraging diversity \\
\cline { 3 - 4 } & & Empathy & Understanding others \\
\cline { 3 - 4 } & & Social skills & $\begin{array}{l}\text { Communication } \\
\text { Building bonds } \\
\text { Collaboration and } \\
\text { cooperation } \\
\text { Team capabilities }\end{array}$ \\
\hline Enjoyment & Self-awareness & & Emotional awareness \\
\hline Expectations & Self-awareness & & Accurate self-assessment \\
\cline { 2 - 4 } & Motivation & & $\begin{array}{l}\text { Achievement drive } \\
\text { Optimism }\end{array}$ \\
\hline Activities & & & \\
\hline Duration & & & \\
\hline
\end{tabular}

\section{Discussion}

With reference to selected examples from the data, this section discusses how the children's data revealed their beliefs that extended provision enabled them to develop motivation for learning and aspirations for the future, as features within a wider range of NCS development across all five of Goleman's EI domains (1995).

\section{Managing self: self-awareness}

Goleman (1995) identifies three sub-sets of self-awareness: emotional awareness, accurate self-assessment and self-confidence, which children's QS responses suggested BU experiences had helped them to develop. They believed BU enhanced their emotional awareness: $93 \%$ indicated BU helped them to feel better about learning and care more about others: 'I really like how all the adults care about the children' and 'Everyone there (at BU) is really lovely and they make us feel welcome'. The consensus in QS responses concerning ways BU had supported them indicated accuracy in their self-assessment: for 20 of 22 statements, $80 \%$ or more children said BU had helped them. Concerning the remaining two statements, $67 \%$ of children said BU helped them to be calmer while $60 \%$ said BU helped them to tell people how they feel about things. Children gave many examples of ways they suggested BU supported their self-confidence and 100\% said that BU had helped them to 'feel more confident'. That confidence was exemplified by their ability to identify the professional careers to which they aspired (Table 1). 
In these ways, children indicated that BU enabled them to recognise their feelings, realistically assess their own abilities, make decisions informed by their own preferences, and gain in self-confidence, aligning with Goleman's definition of self-awareness (2009).

\section{Managing self: self-regulation}

Self-regulation means 'delaying gratification to pursue goals, recovering well from emotional distress' (Goleman, 2009: 318). Children indicated that BU enabled them to develop four aspects of self-regulation (Goleman, 1995): self-control, conscientiousness, adaptability and innovation. John described how BU helped his peer to gain self-control: he learned to 'go and sit on the bench', rather than falling down in tears if a ball hit him during a game. Children also thought BU supported them to be conscientious: all indicated they 'keep on trying at BU even when things are hard', while Jack (aged 8) said BU's Virgin Money Fiver Challenge '...helps me to like spend money wisely'. John (aged 10) was able to adapt first aid skills he had learned at BU to help his friend with the '...massive gash in his knee'. Children also appreciated opportunities for innovation that BU afforded: 'T've been given a charns (sic: chance) to learn new things'.

The children believed BU helped them to develop most aspects of self-regulation, including delaying gratification to pursue goals, and managing emotions to finish tasks or recover from distress; in doing so, they evidenced self-control, conscientiousness, adaptability and innovation (Goleman, 1995; 2009). However, no data emerged to suggest the children believed BU extended provision enabled them to develop trustworthiness, Goleman's fifth aspect of self-regulation (1995).

\section{Managing self: motivation}

Goleman's definition of motivation in the context of EI is defined as 'Using our deepest preferences to move and guide us toward our goals, to help us take initiative and strive to improve, and to persevere in the face of set-backs and frustrations' (2009:318) and it is congruent with Ryan and Deci's description of intrinsic motivation presented above (2000:56). In this study, children indicated that BU had helped them to develop Goleman's four aspects of motivation (1995): achievement drive, commitment, initiative and optimism. Children's thought BU supported their achievement drive: they believed that '...acieving (sic: achieving) my goals' and 'learning' were among the best things about BU. They all said they 'like a challenge' at BU and that BU helped them to 'want to do a great 
job when I am older'; 8-year-old Julian suggested this might be because '(BU) helps you with your homework ...giving me more knowledge...(it) helps you with life beyond'. Equally, children also indicated that BU encouraged their commitment: all the children's QS responses agreed that: 'I always try my best at BU', 'I keep on trying at BU even when things are hard', and 'I always have a go at BU, even when things are hard'. Most children also thought $\mathrm{BU}$ helped them to use their initiative. $80 \%$ said that $\mathrm{BU}$ had helped them to solve problems better' for themselves, while $87 \%$ said BU had helped them to do things for themselves more. Equally, children's identification of 'impediments to learning' at BU indicated their ability to use their initiative to think critically. Children also suggested that BU gave them cause to be optimistic: they aspired to professional careers (Table 1), while Julian (aged 8) thought that BU '...helps you have sport, just because you might want to be a famous something or other' and Jack (aged 8) said street dance experiences at BU might: '...really inspire you and maybe you could become famous'.

The children's data indicated their belief that BU had helped them to 'take initiative... strive to improve, and to persevere' (Goleman, 2009: 381). However, despite their career aspirations, their 'deepest preferences' that Goleman espouses were not revealed in the data, so whether - or how - they might have used these to orientate towards their goals was not clear.

\section{Managing others: empathy}

Goleman (2009: 318) defines empathy as 'sensing what people are feeling, being able to see their perspective, and cultivating rapport and attunement with a broad diversity of people' and he identifies five types of empathy: understanding others, developing others, service orientation, leveraging diversity and political awareness. The children indicated in numerous ways how BU's extended provision gave them opportunities to understand others, exemplified by John's comment that BU had helped his friend to manage his behaviour more positively:

'...he's got anger problems... he's changed after BU, ...changed in a good way.' (John, 10).

The children suggested some ways that BU helped them to develop others, including their peers and BU staff. Jack (aged 8) suggested his idea for staff development: 'there should be more staff (at BU)...two staff in the ICT suite, two staff for sports club, and there's four staff for the whole', while John (aged 10) used what he learned at BU to help his friend to change 
his behaviour after injuring his knee: '...knowing that the first rule in (first aid training) was to keep calm I started telling Julian jokes'. John's example also indicates that BU supported him to practise a service orientation, although there were few other examples of service orientation in the children's data.

Overall, the children thought BU helped them to understand others and, to a lesser extent, to develop others and demonstrate a service orientation. They thought their extended provision helped them to understand others' feelings and perspectives and to develop rapport. However, they did not suggest that extended provision had enabled them to become politically aware or attune to a 'broad diversity of people' (Goleman, 2009: 318). Consequently, children believed that BU enabled them to achieve some empathy skills, but not all.

\section{Managing others: social skills}

Goleman (2009) defines social skills as a collection of abilities: 'Handling emotions in relationships well and accurately reading social situations and networks; interacting smoothly; using these skills to persuade and lead, negotiate and settle disputes, for cooperation and teamwork' (p. 318). Furthermore, Goleman identifies a taxonomy of eight social skills: communication, building bonds, collaboration and cooperation, team capabilities, influence, conflict management, leadership, change catalyst. Only the first four of these were evident in the children's beliefs about extended provision.

Children thought BU offered some opportunities for them to develop communication skills, but they regarded this aspect less positively than other aspects of BU. Only $60 \%$ of responding children said: 'I ask questions about what I do at BU', and 'BU has helped me to tell people how I feel about things'. Additionally, an open questionnaire response from one child - 'People are too noisy and we don't get much done' - suggested that communication at BU was not valued. Children's responses were overwhelmingly positive concerning different ways attending extended provision had helped them to build bonds with others: $87 \%$ said BU had helped them to 'make more friends' and 'care more about other people'. Their open QS responses reinforced this point: features of the extended provision the children liked best included: 'Meeting new friends', '...how all the adults care about the children', 'making friends' and 'Everyone there is really lovely and they make us feel welcome'. Children also indicated that attending extended provision had helped them to acquire collaboration and cooperation skills; $87 \%$ said BU had helped them to 'respect other people more' and John 
exemplified this further in his narrative about using first aid skills he had learned at BU to keep the injured Julian calm: 'I started telling Julian jokes'. There was also evidence that children thought that attending extended provision had helped them to develop team capabilities: 93\% said the extended provision had helped them learn to 'share more with other people' and John's story about his friend who learned to say 'So, it (the ball) hit me, so what? We're playing dodgeball' revealed that extended provision had supported him to develop an understanding of teamwork.

In summary, these data indicate that participating children thought extended provision enabled them to develop certain social skills, but not the full range. Whilst they thought extended provision had helped them to develop skills to communicate, build bonds, collaborate and cooperate, and team capabilities, they did not provide evidence to suggest that they thought their experiences of extended provision had helped them to develop skills in influencing, conflict management, leadership, or catalysing change. The last four of these social skills all require locus of control and their absence from the children's data suggests that the extended provision may not have been effective in transferring power and agency to children, a finding that resonates with extant research (Thornberg and Elvstrand, 2012).

\section{Conclusions, Limitations and Implications}

This article focuses predominantly on views of children aged 7-11 years about ways their experiences of extended provision enabled them to develop NCS. Only brief allusion is made to adult stakeholders from whom data were collected. This is a limitation which inhibits the wider contextual analysis that could have been made had all stakeholders' data been included. However, it allows for more intensive focus on children's views and consequently, the article contributes to redressing the inequity that is children's voices often going unheard in educational contexts and in educational research concerning matters that affect them and about which they are knowledgeable (Langsted, 1994; Redmond, 2008; Singer, 2014).

Because the number of participating children was relatively small, no assumptions can be made that their views represent their peers' perspectives or that findings may be applied to other contexts. Nevertheless, the findings afford authentic insights into the beliefs and attitudes of the participating children concerning their situated context. Moreover, the small size of the focus group was highly conducive to actively and genuinely 'hearing children's voices' (Morgan, Gibbs, Maxwell and Britten, 2002; Brooks and Murray, 2016). 
The adults' data alluded to in this article (Figure 3) highlights that participating parents, teachers and school governors were less positive than children concerning the extent to which extended provision enhanced children's motivation to learn and aspirations for the future. This disjuncture indicates that it cannot be assumed that adults and children share the same views regarding children's learning and suggests that further research that captures children's voices concerning what and how they learn may be valuable to policymakers and educators who make important decisions affecting children's learning.

Children who participated in the study believed their experiences of extended provision featuring life skills activities enabled them to acquire some NCS, including most - but not all - EI competences (Goleman (1995; 2009). This was a small-scale study based on data from one educational setting, for which respondent numbers were low, so it cannot be assumed that the findings are generalisable when taken in isolation. To secure generalisablity, the study would need to be repeated with a representative range of participants in extended provision settings. Nevertheless, the study illuminates practice in the study setting and contributes new findings to corroborate evidence from other research. In a context for which learners' selfbeliefs and NCS are associated with academic achievement (Agasisti and Longobardi, 2016; Durlak et al. 2011; Lin-Siegler et al. 2016; Perez-Gonzalez et al. 2014), it can be argued that experiences the children in this study had of extended provision featuring NCS development may contribute to academic performance gains in the future. This evidence carries messages for statutory education, suggesting that techno-rational educational models that disregard NCS may be counterproductive. Instead of narrow focus on a performativity agenda characterised by teaching to tests (Malaguzzi, in Cagliari et al. 2016; Moss, 2016a), a curriculum for the school day that features NCS development may not only have benefits for NCS development but also for academic performance gains.

Although children in this study reported that their experiences of extended provision enabled them to acquire NCS across all five EI domains (Goleman, 1995; 2009), that provision was planned and guided by adults. The children identified that they were not enabled to acquire social skills that rely on locus of control: skills of influence, conflict management, leadership, and catalyst for change (Goleman, 2009). This finding resonates with extant research revealing a theme of adult empowerment and children's subordination in educational environments (Thornberg and Elvstrand, 2012). In the study setting, because adults did not transfer their power and agency to children, the extended provision did not help children to 
develop the full range of NCS, so its potential to impact positively on learners' academic achievement could not be fully realised.

In summary, this study provides new evidence that children aged 7-11 years believed that extended provision enabled them to develop NCS, including motivation and aspiration for the future. When this finding is combined with extant research suggesting that NCS acquisition leads to academic performance gains (Agasisti and Longobardi, 2016; Durlak et al. 2011; Perez-Gonzalez et al. 2014) it can be argued that the extended provision that supported the children's NCS development may also augment their academic achievement.

\section{References}

Adams, R., S. Weale, H. Bengtsson, and S. Carrell. 2016. "UK schools fail to climb international league table." The Guardian. $6^{\text {th }}$ December, 2016.

Agasisti, T. and S. Longobardi. 2016. Equality of Educational Opportunities, Schools' Characteristics and Resilient Students: An Empirical Study of EU-15 Countries Using OECD-PISA 2009 Data. Social Indicators Research. DOI 10.1007/s11205-016-1464-5

Auld, E. and P. Morris. 2016) "PISA, policy and persuasion: Translating complex conditions into education 'best practice". Comparative Education 52 (2): 202-229.

Baker, W., P. Sammons, I. Siraj-Blatchford, K. Sylva, E. Melhuish, and B. Taggart. 2014. "Aspirations, education and inequality in England: insights from the Effective Provision of Pre-school, Primary and Secondary Education Project." Oxford Review of Education 40 (5): $525-542$.

Ball, S.J. 2003. "The teacher's soul and the terrors of performativity." Journal of Education Policy 18 (2): 215-228.

Ball, S.J. 2012. "Education Reform as Social Barbarism: Economism and the end of authenticity." Práxis Educativa 7 (1): 33-52.

Ball, S.J.2013. Global Education Inc. New policy networks and neoliberal imaginary. London: Routledge.

Bates, A. 2016. "Reculturing schools in England: how 'cult' values in education policy discourse influence the construction of practitioner identities and work orientations." Critical Studies in Education 57 (2): 191-208.

Bedford, S. 2017. "Growth mindset and motivation: a study into secondary school science learning." Research Papers in Education 32 (4): 424-443. 
BERA (2011) Ethical Guidelines for Educational Research. Nottingham: BERA.

Breakspear S. 2012. The Policy Impact of PISA: An Exploration of the Normative Effects of International Benchmarking in School System Performance, OECD Education Working Paper number 71. Paris: OECD

Brody, N. 2004. "What cognitive intelligence is and what emotional intelligence is not." Psychological Inquiry. 15: 234-238.

Brooks, E. and J. Murray. 2016. "Ready, steady, learn: school readiness and children's voices in English early childhood settings." Education 3-13 46 (2): 143-156.

Cleary, T.J. and A. Kitsantas. 2017. "Motivation and Self-Regulated Learning Influences on Middle School Mathematics Achievement.” School Psychology Review 46 (1): 88-107.

Durlak, J.A., R.P. Weissberg, A.P., Dymnicki, E.D. Taylor, and K.B. Schellinger. 2011). "The Impact of Enhancing Students' Social and Emotional Learning: A meta-Analysis of school-based universal interventions." Child Development 82 (1): 405-432.

Fielding, M. 2004. "Transformative Approaches to Student Voice: Theoretical Underpinnings, Recalcitrant Realities.” British Educational Research Journal 30 (2): 295311.

Fielding, M. and P. Moss. 2011 Radical Education and the Common School. London: Routledge.

Fischer, N. and D. Theis. 2014. "Extracurricular Participation and the Development of School Attachment and Learning Goal Orientation: The impact of school quality." Developmental Psychology. 50 (6): 1788-1793.

Fitzpatrick, J.L., J.R. Sanders, and B.R. Worthen. 2010. Program Evaluation: Alternative approaches and practical guidelines. Ontario: Pearson Education.

Gardner, H. 1983. Frames of Mind. New York: Basic Books.

Goleman, D. 1995. Emotional Intelligence. London: Bloomsbury.

Goleman, D. 2009. Working with Emotional Intelligence. London: Bloomsbury

Gorard, S., B.H. See, and P. Davies. 2012. The impact of attitudes and aspirations on educational attainment and participation. York: Joseph Rowntree Foundation.

Grant, T. 2017. "The complexity of aspiration: the role of hope and habitus in shaping working-class young people's aspirations to higher education." Children's Geographies 15 (3): 289-303.

Griffiths, M. 1998. Educational Research for Social Justice. Buckingham: Open University Press. 
Gromada, A. and C. Shewbridge. 2016. "Student Learning Time: A Literature Review", OECD Education Working Papers, No. 127, OECD Publishing, Paris. Accessed: 2.8.18 http://dx.doi.org/10.1787/5jm409kqqkjh-en

Guay, F. 2016. "The virtue of culture in understanding motivation at school: Commentary on the special issue on culture and motivation." British Journal of Educational Psychology 86: 154-160.

Gustafsson, J.-E. 2016. "Lasting effects of quality of schooling: Evidence from PISA and PIAAC.” Intelligence. 57: 66-72

Gutman, L.M. and I. Schoon. 2013. The impact of non-cognitive skills on outcomes for young people: Literature review. London: The Education Endowment Foundation.

Havu-Nuutinen, S. and A. Niikko. 2014. "Finnish primary school as a learning environment for six-year-old preschool children." European Early Childhood Education Research Journal 22 (5): 621-636.

Her Majesty's Government (HMG) (2009) Unleashing Aspiration: The Final Report of the Panel on Fair Access to the Professions. London: The Panel on Fair Access to the Professions.

Holloway, S. L., and H. Pimlott-Wilson. 2011. "Geographies of Children, Youth and Families: Defining Achievements, Debating the Agenda." In Geographies of Children, Youth and Families: An International Perspective, edited by L. Holt, 9-24. London: Routledge.

Hu, W., X. Jia, J.A. Plucker, and X. Shan. 2016. "Effects of a Critical Thinking Skills Program on the Learning Motivation of Primary School Students." Roeper Review. 38 (2): 70-83.

IEA. 2017a. PIRLS. Progress in International Reading Literacy Study. Accessed: 2.8.18. http://www.iea.nl/pirls

IEA. 2017b. TIMSS. Trends in International Mathematics and Science Study. Accessed: 2.8.18. http://www.iea.nl/timss

Jeffrey, B. and G. Troman (Eds.). 2012). Performativity in UK education: ethnographic cases of its effects, agency and reconstructions. Painswick: Ethnography \& Education Publishing.

Kasim, A. and H. Dzakiria. 2001. "Influence of recreation on education aspiration." Asia Pacific Journal of Tourism Research 6 (2): 53-64.

Khattab, N. 2015. 'Students' aspirations, expectations and school achievement: what really matters?” British Educational Research Journal 41 (5): 731-748

Langsted, O. 1994. "Looking at quality from the child's perspective". In Valuing quality in early childhood services: New approaches to defining quality, edited by P. Moss and A. Pence, 28-42. London: Paul Chapman. 
Lincoln, Y.S. and E.G. Guba, E.G. 1985. Naturalistic Enquiry. Newbury Park, CA: Sage.

Lingard, B., J. Nixon, and S. Ranson, S. 2008). "Remaking Education for a Globalized World: Policy and pedagogic possibilities." In Transforming Learning in Schools and Communities. Edited by B. Lingard, J. Nixon, and S. Ranson, 3-36. London: Continuum.

Lin-Siegler, X., C.S. Dweck, and G.L. Cohen. 2016. "Introduction: Instructional Interventions That Motivate Classroom Learning." Journal of Educational Psychology 108 (3): 295-299.

Malaguzzi, L., in Cagliari P., M. Castegnetti, C. Giudici, C. Rinaldi, V. Vecchi, and P. Moss, (Eds). 2016. Loris Malaguzzi and the Schools of Reggio Emilia: A Selection of His Writings and Speeches 1945-1993. Routledge: London.

Marin, T. 2013. "Emotional Intelligence between Science and Art." Euromentor Journal. 4 (2): 111-117.

Matthews, G., M. Zydner, \& R.D. Roberts (Eds.). 2002. Emotional Intelligence: Science and Myth. Cambridge, Mass: The MIT Press.

Maybin, J. 2013 “Towards a Sociocultural Understanding of Children's Voice." Language and Education 27 (5): 383-397.

Mayer, J. D., and P. Salovey. 1997. "What is emotional intelligence?” In Emotional development and emotional intelligence: Educational implications, edited by P. Salovey, and D. J. Sluyter, 3-34. New York: Harper Collins.

McGreer, V. 2004. "The Art of Good Hope." The Annals of the American Academy of Political and Social Science 592: 100-27.

Morgan, M., S. Gibbs, K. Maxwell, \& N. Britten. 2002. "Hearing children's voices: methodological issues in conducting focus groups with children aged 7-11 years." Qualitative Research 2 (1): 5-20.

Moss, G. 2016a "Assessment, accountability and the literacy curriculum: reimagining the future in the light of the past. Literacy. 51 (2): 56- 64.

Moss, P. 2016b. “Early Years PISA Testing.” Early Years Educator 18 (6): 14-16.

Murray, J. and P. Garner. 2015. Social and Emotional Learning Policies and Practices: A Literature Review. UNICEF Report RFPS-USA-2014-501798 (Unpublished).

$\mathrm{Ng}$, C. 2015. "Australian primary students' motivation and learning intentions for extracurricular music programmes.” Music Education Research 19(3): 276-291.

Office of the High Commissioner for Human Rights (OHCHR). 1989. United Nations

Convention on the Rights of the Child. Accessed 2.8.18

http://www.ohchr.org/en/professionalinterest/pages/crc.aspx. 
Ofsted. 2014. The Report of Her Majesty's Chief Inspector of Education, Children's Services and Skills 2013/14. Manchester: Ofsted.

Ofsted. 2018. School Inspection Handbook. Manchester: Ofsted.

Organisation for Economic Cooperation and Development (OECD). 2017a. Programme for International Student Assessment (PISA) Accessed: 2.8.18 http://www.oecd.org/pisa/

Organisation for Economic Cooperation and Development (OECD). 2017b. International Early Learning and Child Well-being Study (IELS). Accessed: 2.8.18 http://www.oecd.org/edu/school/the-international-early-learning-and-child-well-being-studythe-study.htm

Patall, E.A., H. Cooper, and A.B. Allen. 2010. "Extending the School Day or School Year: A Systematic Review of Research (1985-2009)." Review of Educational Research 80 (3): 401436.

Perez-Gonzalez, J.C., M.J. Cejudo-Prado, and C.R. Duran-Arias. 2014. "Emotional intelligence as a non-cognitive predictor of academic performance." Personality and Individual Differences 60 (Supplement): S30.

Pintrich, P.R. 1999. "The role of motivation in promoting and sustaining self-regulated learning." International Journal of Educational Research 31: 459 - 470.

Pintrich, P.R., D.A.F. Smith, T. Garcia, and W.F. McKeachie. 1991. Manual for the Motivated Strategies for Learning Questionnaire (MSLQ). Ann Arbor, MI: NCRIPTAL.

Pratt, N. 2016. "Neoliberalism and the (internal) marketisation of primary school assessment in England." British Journal of Educational Research. 42 (5): 890-905.

Redmond, G. 2008. Children's Perspectives on Economic Adversity: A review of the literature. Innocenti Discussion Paper No. IDP 2008-01. Florence: UNICEF Innocenti Research Centre.

Ryan, R.M. and E.L. Deci. 2000. "Self-Determination theory and the facilitation of intrinsic motivation, social development, and well-being." American Psychologist 55 (1): 58-68.

Salovey, P. and Grewal, D. 2005. "The Science of Emotional Intelligence." Current Directions in Psychological Science. 14 (6): 281-285.

Seldon, A. 2015. Keynote: What Should an Education Be? Tatler Schools Live! Event. Jumeirah Carlton Tower London. $6^{\text {th }}$ October 2015.

Sellar, S., T. Gale, and S. Parker. 2011. "Appreciating aspirations in Australian higher education." Cambridge Journal of Education 41 (1): 37-52.

Singer, A. 2014. "Voices Heard and Unheard: A Scandinavian Perspective." Journal of Social Welfare and Family Law 36 (4): 381-391. 
Taylor, C., and C. Robinson. 2009. "Student Voice: Theorising Power and Participation." Pedagogy, Culture \& Society 17 (2): 161-175.

Thornberg, R. and H. Elvstrand. 2012. “Children's experiences of democracy, participation, and trust in school." International Journal of Educational Research. 53: 44-54.

UNESCO. 2016. Global Educational Monitoring Report. Accessed: 2.8.18. http://en.unesco.org/gem-report/

Van Ryzin, M., A. Gravely, and C. Roseth. 2009. "Autonomy, belongingness, and engagement in school as contributors to adolescent psychological well-being." Journal of Youth and Adolescence 38 (1): 1-12.

Voronova, M.N., A.A. Korneev, and T.V. Akhutina. 2015. "Longitudinal Study of the Development of Higher Mental Functions in Primary School Children." Journal of Russian \& East European Psychology, 52 (3): 16-35.

Whitty, G., and E. Wisby. 2007. "Whose voice? An exploration of the Current Policy Interest in Pupil Involvement in School Decision-Making." International Studies in Sociology of Education 17 (3): 303-319.

Wilhelm, O. 2005. Measures of emotional intelligence: Practice and standards. In R. Schulze \& R. D. Roberts (Eds.) International handbook of emotional intelligence. Pp. 131-154. Seattle, WA: Hogrefe \& Huber.

Winter, C. 2017. "Curriculum policy reform in an era of technical accountability: 'fixing' curriculum, teachers and students in English schools." Journal of Curriculum Studies 49 (1): $55-74$.

World Bank. 2017a. Education. Accessed: 12.8.17.

http://www.worldbank.org/en/topic/education/overview

World Bank. 2017b. Education Statistics. Accessed: 12.8.17.

http://datatopics.worldbank.org/education/

Wünschmann, S., P. Wüst-Ackerman, C. Randler, C. Vollmer, and H. Itzek-Greulich. 2017. "Learning achievement and motivation in an out-of-school setting: Visiting amphibians and reptiles in a zoo is more effective than a lesson at school" Research in Science Education 47: 497-518.

Wyse, D., L. Hayward, and J. Pandya, (Eds.). 2016. The SAGE Handbook of Curriculum, Pedagogy and Assessment. London: Sage. 